\title{
PERBANDINGAN ESTIMASI ANGGARAN BIAYA DAN SCHEDULE PROYEK PEMBANGUNAN RUMAH SAKIT AL HUDA BANYUWANGI MENGGUNAKAN METODE SNI DAN METODE BOW
}

\author{
Mohammad Riski Setio Budi ${ }^{1}$, Suhartinah ${ }^{2}$, Adhitya Surya Manggala ${ }^{3}$ \\ Program Studi Teknik Sipil, Fakultas Teknik, Universitas Muhammadiyah Jember 1,2,3 \\ Jln.Karimata 49, Jember 68121, Jawa Timur \\ email : mriski.setiobudi@gmail.com
}

\begin{abstract}
Cost Budget Plan (RAB) is one of the main processes in a project because it is the basis for making a financing system offer and a budget framework that will be issued. The Budget Plan $(R A B)$ is needed to calculate a building or project with the amount of costs needed for materials, wages and other costs associated with the implementation of the building or project. In this study, the object was used Alhuda Banyuwangi Hospital project. And in this study were used 2 methods for calculating the RAB and schedule, that is the SNI method and the BOW method. Based on the materials that has been processed using 2 different methods, that is the SNI method and the BOW method, it can be seen that there are some things that significant differences. Many things can be known from the differences in the 2 methods, such as the RAB value, time, and number of workers who have differences. The SNI method is more efficient for calculation of RAB, time, and number of workers. Primarily in the planning of many-storey buildings. On the analysis of the unit price known the difference is about $28 \%$ more efficient with the SNI method. There is also a difference in the price of RAB on the SNI method and the BOW method about $36 \%$ more expensive with the BOW method. For the needs of workers it is also more efficient $38 \%$ using the SNI method compared to the BOW method. Based on these differences it is very influential on the weight of a project's work. Therefore, the use of the SNI method is better used in the planning of a project, mainly a multi-storey building
\end{abstract}

Keywords : RAB, BOW, SNI, differences, methods, building planning.

\begin{abstract}
Abstrak
Rencana Anggran Biaya (RAB) merupakan salah satu proses utama dalam suatu proyek karena merupakan dasar untuk membuat penawaran system pembiayaan dan kerangka budget yang akan dikeluarkan. Rencana Anggran Biaya (RAB) diperlukan untuk memperhitungkan suatu bangunan atau proyek dengan banyaknya biaya yang diperlukan untuk bahan, upah serta biayabiaya lain yang berhubungan dengan pelaksanaan bangunan atau proyek tersebut.Dalam studi ini digunakan objek sebuah proyek Rumah Sakit Alhuda Banyuwangi. Serta dalam studi ini digunakan 2 metode untuk perhitungan RAB dan schedule yaitu dengan metode SNI dan metode BOW. Berdasarkan data yang telah di olah menggunakan 2 metode yang berbeda yaitu metode SNI dan metode BOW dapat diketahui bahwa terdapat beberapa hal yang mengalami perbedaan signifikan. Banyak hal yang dapat diketahui dari perbedaan 2 metode tersebut, seperti halnya nilai RAB, waktu, dan jumlah pekerja yang terdapat perbedan. Pada metode SNI lebih efisien untuk peerhitungan RAB, waktu, dan jumlah pekerja. Utamanya pada perencanaan gedung berlantai banyak. Pada analisa harga satuan diketahui perbedaanya yaitu sekitar 28\% lebih efisien dengan metode SNI. Terdapat pula selisih harga RAB pada metode SNI dan metode BOW sekitar 36\% lebih mahal dengan metode BOW. Untuk kebutuhan pekerja juga lebih efisien $38 \%$ menggunakan metode SNI dibandingkan dengan metode BOW. Berdasrkan perbedaan tersebut sangatlah berpengaruh terhadap bobot pekerjaan suatu proyek. Oleh karena itu penggunan metode SNI lebih baik digunakan pada perencanaan suatu proyek utamanya bangunan berlantai banyak.
\end{abstract}

Kata kunci : RAB, BOW, SNI, perbedaan, metode, perencanaan gedung. 


\section{PENDAHULUAN}

\section{Latar Belakang}

Rencana Anggran Biaya (RAB) merupakan salah satu proses utama dalam suatu proyek karena merupakan dasar untuk membuat penawaran system pembiayaan dan kerangka budget yang akan dikeluarkan. Rencana Anggran Biaya (RAB) diperlukan untuk memperhitungkan suatu bangunan atau proyek dengan banyaknya biaya yang diperlukan untuk bahan, upah serta biaya-biaya lain yang berhubungan dengan pelaksanaan bangunan atau proyek tersebut. Mengingat dalam pembuatan ataupun pelaksanaan proyek membutuhkan biaya yang tidak sedikit, untuk itu diperlukan perhitungan-perhitungan yang teliti. Baik dari jumlah biaya pembuatannya, volume pekerjaan, jenis pekerjaan, harga bahan, dan upah kerja. Semua itu bertujuan untuk menekan biaya pembuatan bangunan atau proyek sehingga lebih efisien dan terukur sesuai dengan keinginan atau budget pemilik.

Selain itu penjadwalan proyek pun tidak kalah penting dengan Rencana Anggran Biaya (RAB), karena hal ini sangat berkaitan dengan biaya pengeluaran sebuah proyek konstruksi. Semakin cepat proyek tersebut diselesaikan maka biaya yang dikeluarkan akan semakin kecil pula. Contohnya seperti biaya tukang dan sewa alat per hari. Bukan hanya itu saja, yakni pengiriman bahan baku. Jika schedule telah di buat maka biaya yang ada tidak langsung digunakan untuk membeli semua bahan baku secara langsung, atau dapat digunakan untuk mambeli bahan baku yang diperlukan telebih dulu mengingat jika bahan baku terlalu lama berada di proyek akan semakin besar kemungkinan bahan baku tersebut untuk rusak atau hilang yang disitu akan muncul biaya tak terduga untuk mangganti bahan tersebut.

Rencana Anggaran Biaya dengan metode SNI dan BOW serta mengetahui perbedaan hasil perhitungan anggaran biaya antara metode analisa SNI dan BOW. Selain itu penulis juga tertarik untuk mambuat schedule atau penjadwalan proyek dengan metode Barchart dari hasil analisa RAB dengan metode SNI dan BOW dari pembahasan sebelumnya yang selanjutnya dibandingkan hasilnya untuk mengetahui apa dan seberapa besar pengaruh dari kedua metode tersebut terhadap schedule atau penjadwalan proyek serta untuk mengetahui kelebihan dan kekurangan dari kedua metode.

RAB dari proyek Rumah Sakit Alhuda Banyuwangiini menggunakan metode perhitungan SNI (Standart Nasional Indonesia) yaitu metode yang sering digunakan pada penyusunan anggran biaya di Indonesia. Metode SNI merupakan perbaharuan dari analisis BOW (Burgerlijke Openbare Werken) yang dikembangkan pada tahun 1987 sampai 1991. Hasil penelitian tersebut dituangkan dalam analisa harga satuan biaya konstruksi dalam Standar Nasional Indonesia yang disahkan pada tahun 1991-1992 sebagai metode terbaru dalam penyusunan RAB proyek.

\section{Rumusan Masalah}

Dari latar belakang yang telah diuraikan diatas maka rumusan masalah yang ditinjau antara lain:

1. Berapakah estimasi anggaran biaya yang diperlukan untuk proyek pembangunan Rumah Sakit Al Huda Banyuwangi dengan metode SNI dan BOW?

2. Apa perbedaan dari kedua metode tersebut yakni metode SNI dan BOW?

3. Bagaimana penjadwalan proyek pembangunan Rumah Sakit Al Huda Banyuwangi dari analisa BOW dan SNI dengan metode Barchart?

\section{Tujuan}

Tujuan dari penulisan Tugas Akhir ini adalah:

1. Melakukan estimasi anggaran biaya dengan metode SNI dan BOW pada proyek pembangunan Rumah Sakit Al Huda Banyuwangi untuk mengetahui berapa biaya yang diperlukan untuk pembangunan proyek tersebut.

2. Untuk mengetahui perbedaan dari metode SNI dan BOW sehingga dapat memilih metode mana yang tepat untuk melakukan estimasi anggaran biaya.

3. Memperkirakan rencana durasi dan jumlah pekerja dari proyek pembangunan Rumah Sakit Al Huda 
Banyuwangi dari analisa BOW dan SNI dengan metode Bar chart.

\section{Batasan Masalah}

Adapun batasan masalah pada proposal ini, Sebagai berikut:

1. Penelitian dilakukan pada proyek pembangunan Rumah Sakit Al Huda Banyuwangi.

2. Penelitian ini membahas tentang penyusunan Rencana Anggran Biaya (RAB) proyek pembangunan Rumah Sakit Al Huda Banyuwangi dengan metode SNI dan BOW.

3. Penjadwalan proyek pembangunan Rumah Sakit Al Huda Banyuwangi dengan metode Bar chart.

4. Volume pekerjaan dihitung berdasarkan gambar perencanaan.

5. Data analisa harga satuan yang digunakan adalah AHS dari metode SNI dan BOW.

6. Tidak membahas arsitekture atau estetika desain.

7. Tidak menghitung struktur bangunan.

8. Tidak menganalisa percepatan dari rencana penjadwalan.

9. Tidak menganalisa manajemen pengendalian resiko pengerjaan konstruksi.

\section{Tinjauan Pustaka}

Rencana anggaran biaya dalam sebuah proyek konstruksi perlu dipersiapkan untuk mengetahui biaya yang dibutuhkan dalam proyek. Menurut (Ibrahim, 2001) Yang dimaksud dengan Rencana Anggaran Biaya (Begrooting) suatu bangunan atau proyek adalah perhitungan banyaknya biaya yang diperlukan untuk bahan dan upah serta biayabiaya lain yang berhubungan dengan pelaksanaan Bangunan atau Proyek tersebut.

Anggaran Biaya merupakan harga dari bangunan yang dihitung dengan teliti, cermat dan memenuhi syarat. Anggaran biaya pada bangunan yang sama akan berbeda-beda di masing- masing daerah, disebabkan karena perbedaan harga bahan dan upah tenaga kerja.

Tahap-tahap yang harus dilakukan untuk menyusun anggaran biaya adalah sebagai berikut:

1. Melakukan pengumpulan data tentang jenis, harga serta kemampuan pasar menyediakan bahan/material konstruksi secara kontinu.

2. Melakukan pengumpulan data tentang upah pekerja yang berlaku di daerah lokasi proyek dan atau upah pada umumnya jika pekerja didatangkan dari luar daerah lokasi proyek.

3. Melakukan perhitungan analisis bahan dan upah dengan menggunakan analisis yang diyakini baik oleh si pembuat anggaran.

4. Melakukan perhitungan harga satuan pekerjaan dengan memanfaatkan hasil analisa satuan pekerjaan dan daftar kuantitas pekerjaan.

5. Membuat rekapitulasi.

Sebelum menyusun dan menghitung Harga Satuan Pekerjaan seseorang harus mampu menguasai cara pemakaina analisa harga satuan yang sudah ada. Di indonesia ada 2 macam analisa harga satuan dan bahan antara lain:

a. Metode BOW (Burgeslijke Openbare Werken) adalah suatu ketentuan dan ketetapan umum yang ditetapkan Dir. BOW pada tanggal 28 Februari 1921 nomor 5372 A pada jaman Belanda. Dalam analisa BOW, telah ditetapkan angka jumlah tenaga kerja dan bahan untuk suatu pekerjaan. Prinsip yang terdapat pada metode BOW mencangkup daftar koefisien upah dan bahan yang telah ditetapkan. Keduanya menganalisa harga (biaya) yang diperlukan untuk harga satuan pekerjaan bangunan.

b. Metode SNI, SNI merupakan pembaharuan dari analisa BOW (Burgeslijke Openbare Werken) 1921, dengan kata lain bahwasanya analisa SNI merupakan analisa BOW yang diperbaharui. Analisa SNI ini dikeluarkan oleh Pusat Penelitian dan Pengembangan Pemukiman. Sistem penyusunan biaya dengan menggunakan analisa SNI ini hampir sama dengan sistem perhitungan 
dengan mengguna kan analisa BOW. Prinsip yang mendasar pada metode SNI adalah, daftar koefisien bahan, upah dan alat sudah ditetapkan untuk menganalisa harga atau biaya yang diperlukan dalam membuat harga satu satuan pekerjaan bangunan.

\section{METODE PENELITIAN}

\section{Flow Chart}

Pengolahan data dapat dilihat pada alur pengolahan data pada diagram alur di bawah ini:

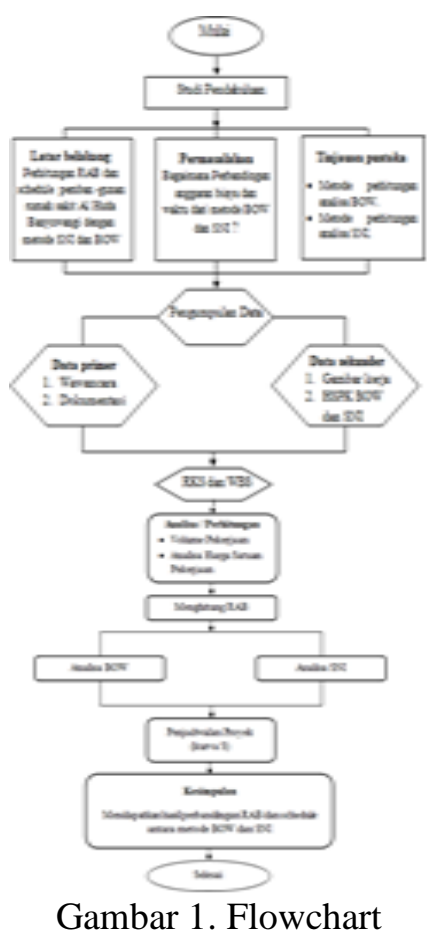

\section{ANALISA DAN PEMBAHASAN}

Studi kasus pada pembahasan Tugas Akhir ini adalah pem bangunan gedung 3 lantai rawat inap dan IBS Rumah Sakit Al-Huda Banyuwangi. Proyek ini berada di jalan Diponegoro no. 65 Genteng, Kabupaten Banyuwangi, Provinsi Jawa Timur. Adapun data proyek sebagai berikut:
1. Luas lahan
$: 4500 \mathrm{~m}^{2}$
2. Jumlah lantai
: 3 lantai
3. Struktur pondasi
: Pondasi mini pile
4. Struktur bangunan
: Beton bertulang
5. Pasangan dinding

dinding bata merah $1 / 2$ bata

6. Struktur atap : Baja konvensional

7. Nilai proyek : Rp.34.158.094.000,00

\section{Analisa Harga Satuan Dengan Metode SNI Dan BOW}

Dalam menghitung dan menyusun Anggaran Biaya suatu bangunan / proyek, harus ber pedoman pada harga satuan bahan dan upah tenaga kerja di pasaran dan lokasi pekerjaan. Sebelum menyusun dan menghitung Harga Satuan Pekerjaan seseorang harus mampu menguasai cara pemakaian analisa harga satuan yang sudah ada.

Karena keterbatasan referensi, peneliti hanya membandingkan Analisa harga satuan yang di kerjakan pada RAB pembangunan gedung 3 lantai rawat inap dan IBS Rumah Sakit Al-Huda Banyuwangi dan item pekerjaan tersebut ada pada kedua metode yaitu metode SNI dan metode BOW saja.

Berikut tabel rekap perban dingan analisa BOW dan SNI

Tabel 1. AHS Dari BOW \& SNI

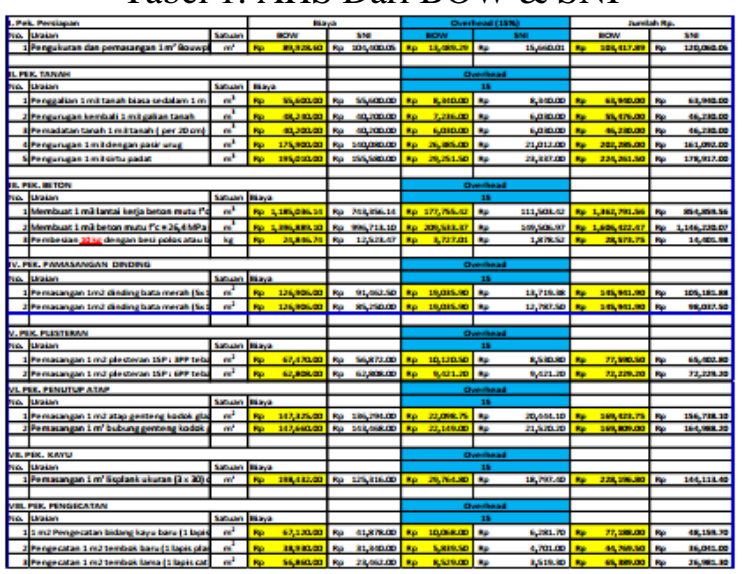

Perbedaan antara analisa BOW dan analisa SNI terdapat pada koefisien bahan dam pekerja. Yang berpengaruh pada harga satuan tiap item pekerjaan. Berdasarkan tabel perbandingan Analisa Harga Satuan di atas maka dapat disimpulkan harga satuan SNI lebih efisien sekitar $\mathbf{2 8 \%}$ daripada harga satuan BOW, meskipun ada beberapa item pekerjaan BOW yang sama bahkan lebih murah daripada SNI. 


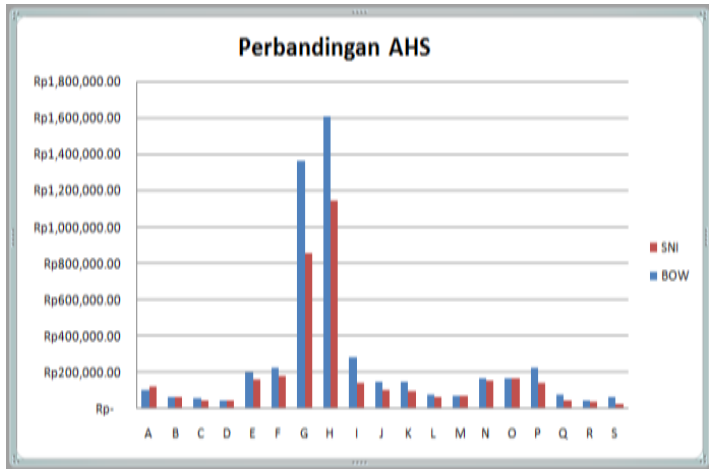

Gambar 2. Perbandingan AHS

\section{Analisa Perhitungan Rencana Anggaran Biaya}

Untuk mencari luasan, pada perhitungan volume rencana anggaran biaya, penulis menggunakan gambar kerja yang telah ada dan dibantu dengan software AutoCAD 2011, luasan dan keliling area dapat diketahui seperti contoh berikut:

Contoh Perhitungan :

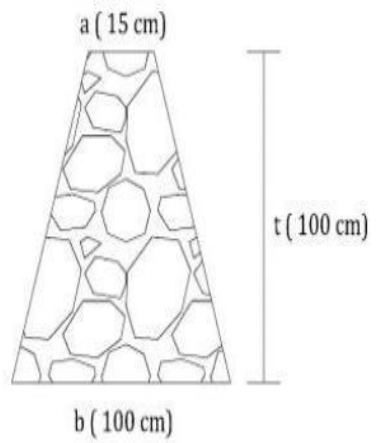

Volume pondasi untuk $1 \mathrm{~m}^{1}$

$\frac{(a+B) x t}{2} \times$ Panjang pondasi

Volume $=$ Luas $\mathrm{x}$ panjang pondasi

$=\frac{(a+b) x t}{2} \times$ Panjang pondasi

$=\frac{(\boldsymbol{a}+\boldsymbol{b}) \boldsymbol{x t}}{\mathbf{2}} \times 1=0.575 \mathrm{~m}^{3}$

Jadi dalam $1 \mathrm{~m}^{1}$ pekerjaan pondasi dengan dimensi seperti di atas volume yang di dapat ialah sebesar $0.575 \mathrm{~m}^{3}$ Selanjutnya menghitung upah dan bahan yang diperlukan.

Bahan = Volume dikali Harga Satuan $1 \mathrm{~m}^{3}$
Pondasi Batu Belah Campuran $1 \mathrm{pc}$ :

$6 \mathrm{pp}$

$=0.575$ x Rp. $735,281,00$

$=$ Rp. $422,786,00$

Berikut adalah rekapitulasi dari Rencana Anggaran Biaya (RAB) berdasarkan metode SNI dan BOW:

Tabel 2. RAB Dari SNI \& BOW

\begin{tabular}{|c|c|c|c|c|c|}
\hline \multirow{2}{*}{ No } & \multirow{2}{*}{ URAIAN } & \multirow{2}{*}{ satuan } & \multicolumn{2}{|c|}{ JUMLAH HARGA } & \multirow{2}{*}{ SELISH } \\
\hline & & & $80 \mathrm{~W}$ & SN & \\
\hline & & & & & \\
\hline 1 & PEKERJAAN PERSIAPAN & $R p$ & $23,786,114,70$ & $27,613,813.23$ & $(3,827,698.52)$ \\
\hline$\|$ & PEKERJAAN TANAH & $R_{p}$ & $356,615,993,60$ & $296,833,804,80$ & $59,782,188.80$ \\
\hline IIII & PEKERJAAN BET ON BERTULANG & $R p$ & $9,517,337,740.80$ & $5,549,269,617,64$ & 3,968,068,123.16 \\
\hline $\mathrm{N}$ & PEKER_JAN AT AP & $R_{p}$ & $352,555,214,24$ & $307,702,840,43$ & $44,852,373.91$ \\
\hline $\mathrm{v}$ & PEKERJAAN DINDING DAN KUSEN & $R p$ & $2,698,894,915,56$ & $2,197,672,070.66$ & $501,222,844,90$ \\
\hline u & PEKERJAAN LANT A DAN DINDING & $R p$ & $195,192,39627$ & $135,023,449.12$ & $60,168,947.15$ \\
\hline $\mathrm{VI}$ & PEKERJAAN CAT & $R_{p}$ & $671,493,229.82$ & $339,917,177.28$ & $331,576,052.54$ \\
\hline \multirow[t]{6}{*}{ WIII } & PEKERJAAN SANTIAR & $R_{p}$ & $37,753,717,33$ & $23,851,922.71$ & $13,901,794.62$ \\
\hline & & & & & \\
\hline & JUMLAH & $R p$ & $13,853,620,322,43$ & $8,877,884,695.87$ & $4,975,744,626.56$ \\
\hline & PPN 105; & $R p$ & $1,385,362,93224$ & $887,788,460.59$ & $497,574,462.66$ \\
\hline & JUMLAH TOTAL & Rp & $15,238,922,254,67$ & $9,765,673,165.45$ & $5,473,319,080.22$ \\
\hline & DIBULATKAN & $\mathrm{Rp}$ & $15,238,922,000.00$ & $9,765,673,000.00$ & $5,473,319,000.00$ \\
\hline
\end{tabular}

Dapat dilihat pada gambar diagram dibawah ini, garis merah adalah garis yang mewakili analisa BOW dan garis biru adalah garis yang mewakili metode SNI. Nilai jumlah anggaran BOW adalah sebesar Rp. $13,853,629,322,-$ dan nilai jumlah anggaran SNI sebesar Rp. 8,877,884,695,- . Selisih jumlah analisa RAB dengan metode BOW sekitar 36\% lebih mahal dari analisa RAB dengan metode SNI.

Kecuali pada pekerjaan per siapan yang pada analisa BOW bernilai Rp. 23,786,144.70 lebih ekonomis daripada hasil dari analisa SNI yang bernilai Rp. 27,613,813.23 atau analisa BOW 16\% lebih ekonomis dibanding analisa SNI.

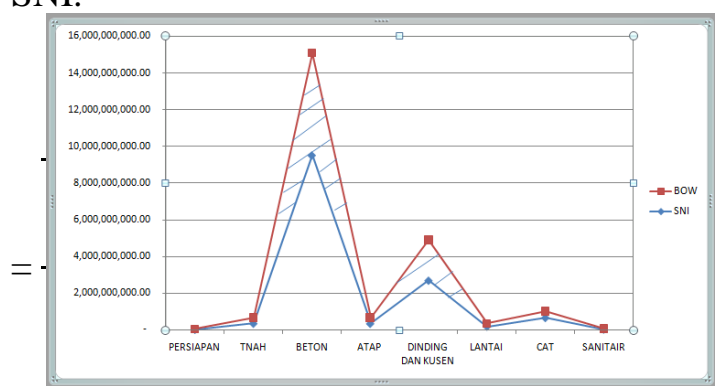

Gambar 3. Perbandingan RAB

\section{Schedule (kurva S)}

Penjadwalan proyek ini meng gunakan metode bar chart atau diagram batang. Diagram batang diisi dengan pembagian bobot atau 
prosentase dari setiap uraian pekerjaan dan perkiraan durasi pengerjaan.

Untuk durasi lama pekerjaan setiap uraian pekerjaan didapat dari koefisien tenaga kerja dari analisa harga satuan (AHS) kemudian dikalikan dengan volume. Dari hasil perkalian tersebut diketahaui berapa jumlah tukang dan berapa durasi yang dibutuhkan untuk setiap uraian pekerjaan.

Catatan: Dalam pembuatan kurva S ini penulis menggunakan semua item pekerjaan meskipun item pekerjaan tersebut tidak dibandingkan pada pembahasan sebelumnya dengan tujuan agar dapat membuat kurva $S$ yang sempurna.

\section{Persentase Bobot Pekerjaan (PBP) :}

$$
\text { PBP }=\frac{\text { Volume } x \text { Harga Satuan }}{\text { Harga Bangunan }} \times 100 \%
$$

Prosentase bobot pekerjaan me rupakan besarnya nilai prosentase tiap uraian pekerjaan yang telah dihitung pada RAB.

Berikut adalah hasil dari per hitungan prosentase bobot pekerjaan dapat dilihat pada tabel berikut:

Tabel 3. Perbandingan Bobot RAB

\begin{tabular}{|c|l|r|r|}
\hline \multirow{2}{*}{ NO } & \multirow{2}{*}{ URAIAN } & \multicolumn{2}{c|}{ BOBOT } \\
\cline { 3 - 4 } & & \multicolumn{1}{|c|}{ BOW } & \multicolumn{1}{c|}{ SNI } \\
\hline I & PEKERJAAN PERSIAPAN & 0.678 & 0.800 \\
\hline II & PEKERJAAN TANAH & 0.989 & 0.956 \\
\hline III & PEKERJAAN PONDASI & 2.567 & 2.980 \\
\hline IV & PEKERJAAN BET ON BERTULANG & 26.638 & 18.143 \\
\hline V & PEKERJAAN AT AP & 5.753 & 6.534 \\
\hline VI & PEKERJAAN DINDING DAN KUSEN & 17.234 & 18.395 \\
\hline VII & PEKERJAAN PLAFOND & 3.242 & 3.760 \\
\hline VIII & PEKERJAAN LANT AI DAN DINDING & 13.022 & 14.923 \\
\hline IX & PEKERJAAN CAT & 1.863 & 1.095 \\
\hline $\mathrm{X}$ & PEKERJAAN SANIT AIR & 1.772 & 2.013 \\
\hline $\mathrm{XI}$ & PEKERJAAN LAIN - LAIN & 1.314 & 1.525 \\
\hline $\mathrm{XII}$ & PEKERJAAN MEKANIKAL ELEKTRIKAL & 24.926 & 28.877 \\
\hline & \multirow{2}{*}{ JUMLAH } & 100 & \\
\cline { 3 - 4 } & & & 100 \\
\hline
\end{tabular}

\section{Perhitungan Durasi Dan Jumlah Tukang Yang Dibutuhkan}

Durasi dan kebutuhan pekerja didapat dari koefisien tenaga kerja dari analisa harga satuan (AHS) kemudian dikalikan dengan volume tiap pekerjaan.
Contoh: PEKERJAAN TANAH

Tabel 4. AHS Pekerjaan Tanah

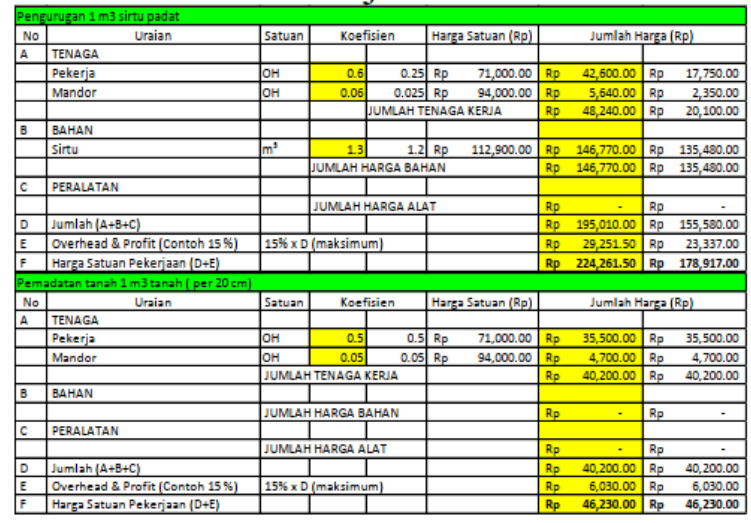

Dari tabel diatas dapat dihitung kebutuhan pekerja dan waktu perencanaan durasinya dengan cara dibawah ini:

Tabel 5. Kebutuhan Pekerja \& Durasi

\begin{tabular}{|c|c|c|c|c|c|c|c|c|c|c|c|}
\hline \multirow[t]{2}{*}{ No } & \multirow[t]{2}{*}{ URAIAN } & \multirow{2}{*}{\multicolumn{2}{|c|}{ VOLUUE }} & \multicolumn{2}{|c|}{$\begin{array}{l}\text { KOEFISIEN PEXERJA } \\
\text { (GABUNGAN) }\end{array}$} & \multicolumn{2}{|c|}{$\mathrm{OOH}$} & \multicolumn{2}{|c|}{ DURASI } & \multicolumn{2}{|c|}{\begin{tabular}{|c|} 
KEEB. PEEERNAA \\
(I HARI) \\
\end{tabular}} \\
\hline & & & & \begin{tabular}{|l|}
$80 W$ \\
\end{tabular} & SW & BOW & SWI & Bow & SN & \begin{tabular}{|l|}
$50 W$ \\
\end{tabular} & $S N$ \\
\hline III & PEKERJAAN TANAH & & & & & & & & & & \\
\hline & Peningjan Elvasi Tanah & $1,318.40$ & $\mathrm{~m}^{3}$ & 0.66 & 0.55 & 870.14 & 725.12 & & & & \\
\hline 2 & Pembdatan Tanah & $1,318.40$ & $\mathrm{~m}^{3}$ & 0.55 & 0.55 & 725.12 & 725.12 & & & & \\
\hline & Subjumlah & & & & & 1,59526 & 1,45024 & 12 & 12 & 1329 & 120.9 \\
\hline
\end{tabular}

1. Jumlahkan koefisian pekerja yang dibutuhkan untuk kedua item pekerjaan tersebut (anggap mandor dan tukang adalah sama)

A. Peninggian elevasi tanah (lihat tabel 4.7)

$$
=0,6+0,06=0,66
$$

B. Pemadatan tanah (lihat tabel 4.7)

$$
=0,5+0,05=0,55
$$

2. Hitung volume pekerjaan tanah lalu kalikan dengan koefisien pekerja pada pekerjaan tersebut (dalam pekerjaan ini volume yang akan dikerjakan adalah $1318,4 \mathrm{~m}^{3}$ )

A. Peninggian elevasi tanah (lihat tabel 4.8)

$$
\begin{aligned}
& =0,66 \times 1318,4 \\
& =870,14 \mathrm{O} / \mathrm{H}
\end{aligned}
$$

B. Pemadatan tanah (lihat tabel 4.8)

$$
\begin{aligned}
& =0,55 \times 1318,4 \\
& =725,12 \mathrm{O} / \mathrm{H}
\end{aligned}
$$

3. Hitung kebutuhan pekerja dengan durasi yang telah direncanakan (untuk pekerjaan tanah direncanakan diselesaikan dalam waktu $2 \times 6$ hari $=$ 
12 hari)

A. Peninggian elevasi tanah (lihat tabel 4.8)

$$
=\frac{870,14}{12}=72,5 \mathrm{O} / \mathrm{H}
$$

B. Pemadatan tanah (tabel 4.8)

$$
=\frac{725,12}{12}=60,4 \mathrm{O} / \mathrm{H}
$$

4. Jumlahkan kebutuhan pekerja untuk kedua item pekerjaan tersebut

Peninggian elevasi tanah + pemadatan tanah

$$
\begin{aligned}
& =72,5+60,4 \\
& =132,9 \stackrel{133 \mathrm{O} / \mathrm{H}}{\longrightarrow}
\end{aligned}
$$

Jadi untuk pekerjaan Tanah dengan volume pekerjaan $1318,4 \mathrm{~m}^{3}$ dengan waktu rencana 12 hari atau 2 minggu memerlukan pekerja sejumlah 133 orang pekerja disetiap harinya dalam 12 hari.

Berikut tabel perhitungan untuk kebutuhan

\begin{tabular}{|c|c|c|c|c|c|c|c|c|}
\hline \multirow{2}{*}{ No } & \multirow[t]{2}{*}{ URAIAN PEKERJAAN } & \multicolumn{2}{|c|}{$\mathrm{O} / \mathrm{H}$} & \multicolumn{2}{|c|}{ DURASI } & \multicolumn{2}{|c|}{\begin{tabular}{|c|} 
KEB. PEKERJA \\
(1 HARI)
\end{tabular}} & \multirow{2}{*}{ KODE } \\
\hline & & Bow & $S N I$ & BOW & $S N I$ & $B O W$ & $S \mathrm{NI}$ & \\
\hline 1 & PEKERJAAN PERSIAPAN & 503.55 & 50585 & 240 & 240 & 210 & 2.108 & A \\
\hline i1 & PEKERJAAN TANAH & $1,595.26$ & \begin{tabular}{|l|l|}
$1,450.24$ \\
\end{tabular} & $\frac{12}{12}$ & 12 & 132.9 & 120.9 & B \\
\hline IIII & PEKERJAAN PONDASI & 350 & 350 & 36 & 36 & 9.7222 & 9.722 & c \\
\hline \multirow[t]{6}{*}{ IV } & \multicolumn{2}{|c|}{ PEKERJAAN BETON BERTULANG } & & & & & & \\
\hline & LANTAI 1 & $2,278.36$ & 774.19 & 36 & 36 & 63.29 & 21.51 & D \\
\hline & \begin{tabular}{|l|} 
LANTAI 2 \\
\end{tabular} & 4.112 .72 & $\begin{array}{l}1,312.75 \\
\end{array}$ & 48 & 48 & 85.68 & 27.35 & $\bar{E}$ \\
\hline & LANTAI 3 & \begin{tabular}{|l|l|l}
3.907 .47 \\
\end{tabular} & 1.247 .24 & 42 & 42 & 93.04 & 29.70 & \\
\hline & LANT & $1,434.99$ & 505.51 & 30 & 30 & 47.83 & 16.85 & G \\
\hline & LANT & 186.36 & 65.10 & 6 & 6 & 31.06 & 10.85 & $\mathrm{H}$ \\
\hline $\mathrm{v}$ & PEKERJAAN ATAP & $8,059.38$ & $7,602.22$ & 42 & 42 & 191.9 & 181.0 & $\mathrm{~T}$ \\
\hline \multirow[t]{5}{*}{$\mathrm{n}$} & \multicolumn{4}{|c|}{ PEKERJAAN DINDING, KUSEN PINTU DAN JENDELLA } & & & & \\
\hline & LANTAI 1 & 5.031 .76 & 4.231 .46 & 66 & 66 & 76.24 & 64.11 & \\
\hline & LANTAI 2 & 7.680 .71 & 6.508 .63 & 66 & 66 & 116.4 & 98.6 & $\mathrm{~K}$ \\
\hline & LANTAI 3 & $7,266.64$ & $6,172.93$ & 60 & 60 & 121.1 & 102.88 & $\mathrm{~L}$ \\
\hline & LANTAI ATAP LIFT & 265.93 & 204.23 & 6 & 6 & 44.32 & 34.038 & M \\
\hline \multirow{5}{*}{ vil } & PEKE & & & & & & & \\
\hline & LANT & 55.17 & 5.17 & 60 & 60 & 6.75 & 6.75 & $\mathbf{N}$ \\
\hline & \begin{tabular}{|l|} 
LANT \\
\end{tabular} & |508.85 & 508.85 & 60 & 60 & 8.48 & 8.48 & o \\
\hline & LANT & 436.58 & 436.58 & 54 & 54 & 8.08 & 8.08 & 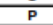 \\
\hline & $\begin{array}{l}\text { LANTAI ATAP LIFT } \\
\end{array}$ & 35.25 & 27.06 & 8 & 6 & 5.87 & 4.5098 & a \\
\hline VIII & \multicolumn{3}{|c|}{ PEKERJAAN KERAMIK LANTAI DAN DINDING } & & & & & \\
\hline & LANTAI 1 & $3,680.68$ & $3,127.08$ & 72 & 72 & 51.12 & 43.43 & $\mathbf{R}$ \\
\hline & LANT & 4.041 .70 & 4.032 .24 & 72 & 72 & 56.13 & 56.00 & $\mathrm{~s}$ \\
\hline & LANTAI 3 & $2,881.27$ & $2,873.14$ & 72 & 72 & 40.02 & 39.90 & $T$ \\
\hline & LANTAI & 29.78 & 7.09 & 18 & 18 & 1.65 & 0.39 & u \\
\hline \multirow[t]{5}{*}{$\mathrm{IX}$} & PEKERJAAN CAT-CATAN & & & & & & & \\
\hline & LANTA & $1,085.19$ & 206.88 & 72 & 72 & 15.07 & 2.87 & $\mathbf{v}$ \\
\hline & LANT & $1,779.38$ & 339.23 & 72 & 72 & 24.71 & 4.71 & w \\
\hline & LANTAI 3 & $1,884.10$ & 387.01 & 72 & 72 & 26.17 & 5.38 & $\bar{x}$ \\
\hline & LANT & 82.88 & 16.38 & 12 & 12 & 6.91 & 1.37 & $\mathrm{Y}$ \\
\hline \multirow[t]{4}{*}{$\bar{x}$} & PEKEE & & & & & & & \\
\hline & LAN & 755.87 & 07 & 36 & 36 & 21.00 & 17.03 & $z$ \\
\hline & & 292.34 & & 36 & 36 & 8.1 & 8.02 & A1 \\
\hline & & & & 30 & 30 & 38 & 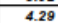 & B1 \\
\hline$x \mid$ & LAIN - LAIN & 161.00 & 161.00 & 78 & 78 & 2.06 & 2.06 & c1 \\
\hline xII & PEKERJAAN ELEKTRIKAL & 3.230 .42 & $3,230.42$ & 150 & 150 & 21.54 & 21.54 & D1 \\
\hline
\end{tabular}
durasi dan pekerja dengan 2 analisa yaitu SNI dan BOW:

Tabel 6. Durasi \& Kebutuhan Pekerja

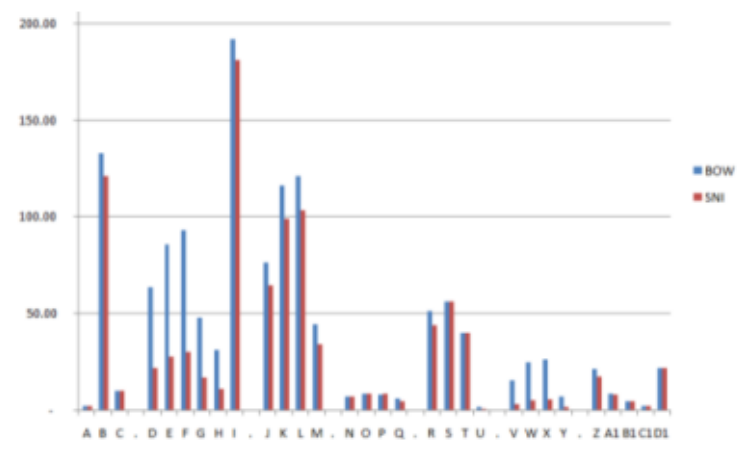

Gambar 4. Grafik Kebutuhan Pekerja

Dari tabel di atas dapat dilihat perbedaan yang sangat signifikan untuk kebutuhan pekerja dari analisa BOW berselisih sekitar $\mathbf{3 8 \%}$ lebih banyak dari analisa SNI. Hal itu dikarenakan pada saat zaman Belanda ada kebijakan padat karya yang membuat jumlah pekerja saat itu sangat padat atau banyak, sehingga berpengaruh pada koefisien pekerja yang dimana pada bagian itulah perbedaan dari kedua analisa tersebut yakni analisa BOW dan SNI.

\section{Kurva $S$}

Dari rencana durasi waktu tersebut, kemudian dapat dibuat diagram balok dan kurva "S" dari hubungan prosentase komulatif dengan durasi waktu yang direncanakan. Diagram balok dan kurva "S" dapat dilihat pada tabel time schedule berikut:

Kurva "S" tersebut meng gunakan seluruh item pekerjaan yang pada pembahasan sebelumnya tidak dibandingkan. Kedua kurva ini menggunakan jumlah durasi perencanaan yang sama agar dapat diketahui apa saja pengaruh dari kedua analisa tersebut pada schedule atau kurva perencanaan.

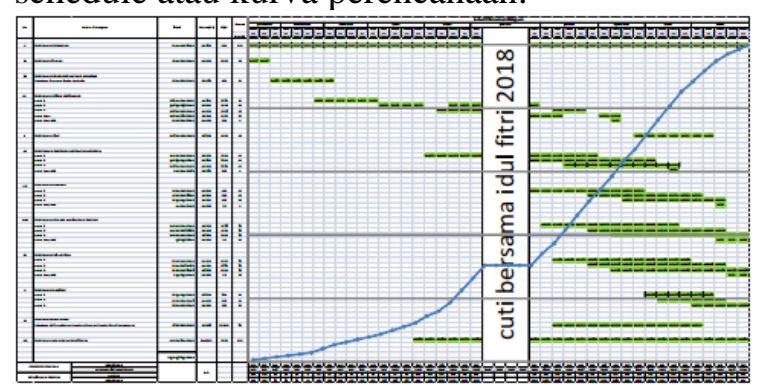

Gambar 5. Kurva S Dari SNI 


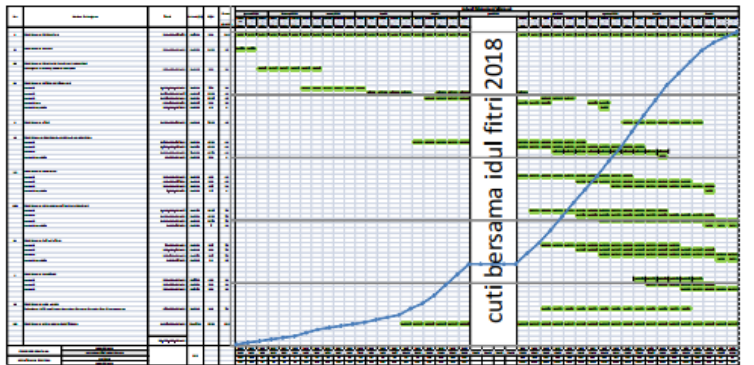

Gambar 6. Kurva S Dari BOW

Dari kuva "S" tersebut dapat dilihat, besarnya anggaran biaya yang yang dipengaruhi oleh koefisien bahan dan pekerja yang berbeda pada tiap analisa maka berpengaruh juga pada jumlah bobot pekerjaan dan jumlah pekerja di tiap minggunya tanpa merubah bentuk kurva dan durasi perencanaannya. Contohnya (lihat pada lampiran 4) pada analisa BOW diminggu ke 7 memerlukan pekerja sejumlah 75 orang tiap hari dalam semingu atau 451 orang tiap minggunya, sedangkan pada analisa SNI memerlukan pekerja sejumlah 33 orang tiap hari dalam seminggu atau 200 orang tiap minggunya.

\section{KESIMPULAN DAN SARAN}

\section{Kesimpulan}

Dari hasil penelitian diatas mengenai Perbandingan Estimasi Anggaran Biaya Dan Schedule Proyek Pem bangunan Rumah Sakit Al Huda Banyuwangi Menggunakan Metode Sni Dan Metode Bow dapat disim pulkan sebagai berikut:

1. Pada Analisa Harga Satuan, Perbedaan antara analisa BOW dan analisa SNI terdapat pada koefisien bahan dan pekerja yang berpengaruh pada harga satuan tiap item pekerjaan. Dari hasil analisa dapat disimpulkan harga satuan analisa SNI sekitar 28\% lebih efisien daripada harga satuan BOW.

2. Untuk perhitungan $R A B$, Nilai jumlah anggaran BOW adalah sebesar Rp. 13,853,629,322,- dan nilai jumlah anggaran SNI sebesar Rp. $\mathbf{8 , 8 7 7 , 8 8 4 , 6 9 5 , - . ~ S e l i s i h ~ j u m l a h ~ a n a l i s a ~}$ RAB dengan metode BOW sekitar 36\% lebih mahal dari analisa $\mathrm{RAB}$ dengan metode SNI.
3. Dari kurva "S" yang telah diteliti dengan analisa SNI dan BOW, dapat dilihat besarnya anggaran biaya yang dipengaruhi oleh koefisien bahan dan pekerja yang berbeda pada tiap analisa maka berpengaruh juga pada jumlah bobot pekerjaan dan jumlah pekerja di tiap minggunya tanpa merubah bentuk kurva dan durasi perencanaannya.

4. Kebutuhan pekerja dari analisa SNI lebih efisien sekitar 38\% dari BOW.

\section{Saran}

Adapun saran untuk Tugas Akhir ini antara lain:

1. Di dalam menghitung harga satuan pekerjaan sebaiknya dilakukan perhitungan dengan lebih teliti, khususnya pemilihan metode perhitungan yang tepat sehingga didapatkan anggaran biaya yang ekonomis serta dapat dipertanggung jawabkan

2. Penelitian selanjutnya dapat menganalisa percepatan proyek dari timeschedule yang ada dapat dibantu dengan beberapa aplikasi seperti MS PROJECT dan yang lainnya.

3. Perlu adanya AHS dengan item pekerjaan yang mengunakan alat seperti memasang pondasi pancang, pengerukan tanah dengan excavator, pengecoran dengan Concrete Mixer Truck dan Concrete Pump dan pekerjaan - pekerjaan lainnya.

\section{DAFTAR PUSTAKA}

Redaksi Bumi Aksara., 2011, "Analisa Upah Dan Bahan (Analisa Bow)", Jakarta: PT. Bumi Aksara.

Darmawan, Dicky., 2017, "Estimasi Anggran Biaya dan Waktu Pem bangunan Pusat Kajian Islam di Fakultas Teknik Universitas Jember". Jember: Universitas Jember.

Rahman, Abd., 2014, "Perbandingan Estimasi Anggran Biaya Antara Metode SNI Dan BOW Pada Proyek Pembangunan Gedung Joang / Legion Veteran Repu blik Indonesia". Samarinda : Universitas 17 Agustus 1945 Samarinda. 
Mahardika Rahmawan Putra, Nur Azizah Afanndy., 2017, "Perbandingan Estimasi Anggran Biaya Antara Metode SNI Dan $B O W$ ". Lamongan : Universitas Islam Lamongan.

Herwansyah, diyan., 2014. "Estimasi Anggran Biaya Konstruksi Dan Rencana Penjadwalan Tahap Desain Pada Pembangunan Kampus BSI MargondaDepok". Depok.

Fatonah, Kurnia. Wulansari, Dwi Novi., 2014, "Estimasi Anggaran biaya Struktur Proyek Pemba ngunan Hotel Quad Makasar Menggunakan Metode SNI". Jakarta : Universitas 17 Agustus 1945 Jakarta.

Mochamad Amin Dieng Permana, Saifoe El Unas, Eko Andi Suryo., 2015. "Analisis Biaya Rumah Pracetak Berdasarkan Software Microsoft Project Di Perumahan Bulan Terang Utama Malang”. Malang : Universitas Brawijaya Malang.

Rozi Kurniawan, M. Hamzah Hasyim, Saifoe El Unas., "Analisa Perbandingan Metode SNI Dan Software MS. Project Dalam Perhitungan Harga Satuan Pekerjaan Penutup Lantai dan Dinding Serta Pemasangan Paving Block Untuk Konstruksi Bangunan”. Jurusan Teknik Sipil - Fakultas Teknik Universitas Brawijaya. 